chemical and other kinetic investigations have been made on ether, acetone, acetaldehyde, ethylene oxide and a number of hydrocarbons. Radioactive carbon is being used for labelling particular functional groups to follow their course in photochemical reactions. The compressibility of pure helium in the temperature range $0-600^{\circ} \mathrm{C}$. has been determined with a high degree of accuracy. Work has continued on the infra-red spectra of complex organic compounds, especially those of biological importance, and on plant alkaloids, particularly on the chemical constitution of those alkaloids previously discovered in the laboratory ; the investigation of the acid-dyeing of wool has also continued.

Besides its advisory functions to other government departments on the supply or testing of chemicals, the Applied Chemistry Branch is investigating the use of the fluidized bed technique for the recovery of oil from Athabaska tar sands, the mechanism of detergency and of the inhibition of corrosion by silicates and chromates, the high-temperature corrosion of heat-resistant alloys, the evaluation of anti-freeze materials as regards the corrosion of the cooling system of internal combustion engines, and the occurrence, purification and chemistry of natural and synthetic unsaturated fatty acids. Problems relating to the use of a Canadian-produced synthetic rubber have been investigated in collaboration with the Polymer Corporation, and work on the catalytic oxidation of ethylene to ethylene oxide has been directed towards acquiring the engineering data for the design of a pilot plant. Some work has been done in extension of Reppe's work on the synthesis of acetylene derivatives. Investigations in the Division of Mechanical Engineering have included further work on the control and stability of tailless aircraft and on the model of the Fraser River, and problems in connexion with the use of fuels and lubricants at low temperatures. The design and construction of special instruments required in the laboratories is a responsibility of the instrument laboratory.

The Division of Physics made plans for a spectroscopy group in July 1948, and the building up of equipment for precision electrical standards and work continued on the thermostatic control of refrigerator cars as well as on the colorimetry of railway fusees. Investigations were initiated on the possibilities of a camera mount with very soft restraints for minimizing the effect of pitch, yaw and roll on image movement in air photography and on the factors affecting the resolving power in a print made by a projection. The Division of Radio and Electrical Engineering was occupied mainly in fundamental research in radar and radiophysics and application of radar techniques to peace-time problems, including the development of two electrostatic generators of the Van de Graaff type and a study of methods of applying Shoran radar techniques in measuring the distance between two fixed points on the ground with sufficient accuracy for geodetic purposes and in determining the position of an aircraft engaged in taking photographs at intervals along a flight line.

The research programme of the Division of Medical Research is entirely extra-mural, and 118 projects were supported during the year, including fundamental research on such subjects as the physiology and biochemistry of muscular activity, cellular development, growth, destruction and regeneration; the physiology and biochemistry of nervous and special-sense activity; mechanisms of secretion; metabolic studies, including the role of vitamins; and studies on blood constituents, including the cells, enzymes, lipids and clotting agents. Thirty medical fellowships were held at seven universities during the year ; the Council also granted 169 scholarships for postgraduate work, and 148 were actually held as against 145 in the previous year, mainly in physics (51), physical chemistry (29), chemistry (14) and organic chemistry (13). The work of the Technical Information Service also substantially increased, and the section now handles about four hundred inquiries a month. Pending the development of a national library in Canada, the library of the Council endeavours to provide some of the services which the science branch of such a national library might give.

\section{RESIDENTIAL COURSES FOR SUPERVISORS}

$\mathrm{A}$ MONG the subjects discussed at the British Institute of Management Conference at Margate in 1949 was whether there is a need for short residential courses to be provided on a national scale for foremen and supervisors. The subject was introduced by Major W. F. Scott, director of training to Tube Investments, Ltd., who stated that during the past thirty years the number of people employed in large businesses has greatly increased, processes of production have become much more scientific, and autocratic management has either yielded place to democratic or is fighting a hopeless rearguard action. Industry rests to-day upon the willingness of the operative to perform his task, and the supervisor is the propeller shaft linking the motive power of management with the operative. The link, therefore, should be fit for its important function, and this implies good initial selection and training of supervisors followed by some method of ensuring that he is kept up to date on all developments, technical, administrative and psychological, which affect his daily life.

Under the old order, the foreman's principal tool of control was the power of dismissal, but the stress and strains of war and the need for higher production under the conditions of the Essential Work's Order laid bare the weaknesses in this system. In most factories it was necessary to introduce one ancillary department after another, and each of them removed from the foreman's authority some function which had previously been his unchallenged prerogative. In the pressure of events, little was done to make him understand why changes were necessary.

Efforts to solve the difficulty were made by many technical colleges, which arranged special courses for foremen during the evenings; but their total impact on the problem was small. The Training Within Industry Scheme which was introduced from the United States also proved a useful help to the supervisor; but it did little to re-orientate him to the changed environment of an industrial world of full employment and a more complicated administrative structure. Supervisors' societies have also grown in number, and the Institute of Industrial Supervisors has come into being for the express purpose of helping its members to a better understanding of their jobs.

It is significant, however, that several large industrial organisations have come to the conclusion that something more is needed and have instituted internal courses for their supervisors. A few of these courses are residential in character, and with these, 
Major Scott suggested, the advantages accruing from residence outweighed the added cost involved. But there are few concerns in Great Britain which are big enough to be able to organise their own courses and, if there is need for additional training facilities beyond those provided by technical colleges, the need must be met by industry combining to provide the instruction required under the conditions which will make it most effective. Residential training is essential owing to the short time that supervisors can be away from their jobs and because it ensures that every waking hour of that absence will play its part in making the training effective.

During the discussion most speakers agreed that such residential establishments could play a useful part in national recovery, although $\mathrm{Mr}$. R. R. Hopkins, of Vauxhall Motors, Ltd., believed that the number of men who would benefit from fortnightly courses would be so small that it might be better to arrange for a much bigger number of foremen to attend courses of shorter duration. Dr. I. Blain, of the National Institute of Industrial Psychology, described experiences which had been obtained during an investigation which some members of the Institute's staff have been carrying out during the last few months. Foremen who have already attended such courses as these proposed by Major Scott believe that the real value of the courses comes from personal contacts rather than from the content of the course. Supervisors find it difficult to understand the general principles which it is feasible to teach them in a course of a rather academic type, and they do not know how to apply these general principles to the specific practice which holds in their organisations. Such courses, therefore, should be supplementary only to the training processes which should go on continuously within the individual companies. $\mathrm{Mr}$. N. C. Rimmer, of the British Institute of Management, brought out the important point that the number of people attending each course should be limited and also that the atmosphere provided should be conducive to development of the co-operative spirit.

A plenary session of the Conference agreed that residential courses for foremen training should be set up throughout the country and that the British Institute of Management should use its efforts to further the study of the problem, to stimulate the provision of facilities in all suitable establishments, to co-ordinate and assist endeavours, to promote further experiments, and to encourage the full use by industry of the opportunities so provided.

\section{T. H. HAwKINS}

\section{M.K.S. SYSTEM OF ELECTRICAL UNITS}

$I^{T}$ is now some forty-nine years since Prof. Giorgi first put forward his proposal for the establishment of a system of units based on the electrotechnical practical units together with the metre, the kilogram and the second as an alternative to the centimetre-gram-second electrostatic and electromagnetic systems. This system of Prof. Giorgi, now commonly known as the M.K.S. System, was accepted by the International Electrotechnical Commission in 1935, and in 1948 the absolute volt and absolute ampere were introduced internationally as a result of a decision of the Comité International des Poids et Mesures taken in 1946.
It might be thought that a matter upon which these international decisions had been taken after searching examination over so long a period would be one in which there could be little room for further discussion, and that by this time the M.K.S. System would have taken its place in the general practice of electrical engineering. "Future practice," wrote Giorgi in his memorandum of 1934 for the International Electrotechnical Commission, "will show which units are the most convenient for every particular purpose and the law of the 'survival of the fittest' will receive application." The fact is, however, that the adoption of the M.K.S. System has proceeded relatively slowly.

In two publications recently reprinted from Philips Research Reports, "The Rationalised Giorgi System and its Consequences" by P. Cornelius and H. C. Hamaker, and "Proposals and Recommendations Concerning the Definitions and Units of Electromagnetic Quantities" by P. Cornelius, the essential features of the M.K.S. System are re-stated, the position of the system reviewed and specific recommendations are made regarding it. It is particularly interesting that these two papers originate from an industrial organisation, as one of the reasons sometimes adduced for the slow progress in the adoption of M.K.S. units is that the main advantages of the system lie rather in the academic sphere and that the practising engineer or scientific worker is not as a rule greatly concerned about the matter. The firstmentioned paper gives an excellent account of the basis of the system and deals in some detail with the various controversial issues which have emerged in connexion with it, notably that of the $E-H$ and $E-B$ analogies. The case for rationalization, which is not, of course, specific to the M.K.S. System but has become inextricably linked with it, is cogently argued.

University and technical college teachers of pure or applied science will find much of interest in these communications. The ultimate benefit to the science and practice of electrical engineering of teaching students on the basis of a single unitary system can scarcely be called in question, and the problem of how best to incorporate M.K.S. units into the general structure of electrical engineering courses has become an urgent matter. It may be noted, in this connexion, that on March 30 a symposium of papers on the M.K.S. System of units will be presented to the Institution of Electrical Engineers.

JaMES Greig

\section{ENERGY OF THE STARS}

HE Halley Lecture for 1949 was delivered at Oxford on May 12 by Dr. R. d'E. Atkinson, who chose "The Energy of the Stars" for his subject (The Observatory, 69, 851 ; October 1949); as its scope is very comprehensive, it is quite impossible to give more than a mere outline of the points dealt with.

In the Lecture a short historical sketch is given of the problem of stellar energy from the days when it was thought that radioactivity provided a solution, up to recent times. This deals with the work of Eddington, Gamow, Houtermans, Russell and many others, including that of Atkinson himself, who has devoted a considerable amount of time to the subject during the past twenty years. Present nuclear theories are unsatisfactory in certain respects, and 